\title{
Constrained enrichment contributes to hypoxia formation in Long Bay, South Carolina (USA), an open water urbanized coastline
}

\author{
D. M. Sanger ${ }^{1, *}$, E. M. Smith ${ }^{2}$, G. Voulgaris ${ }^{2}$, E. T. Koepfler ${ }^{3}$, S. M. Libes ${ }^{3}$, \\ G. H. M. Riekerk ${ }^{4}$, D. C. Bergquist ${ }^{4}$, D. I. Greenfield ${ }^{2,4}$, P. A. Wren ${ }^{3}$, C. A. McCoy ${ }^{1,3}$, \\ R. F. Viso ${ }^{3}$, R. N. Peterson ${ }^{3}$, J. D. Whitaker ${ }^{4}$ \\ ${ }^{1}$ South Carolina Sea Grant Consortium, Charleston, South Carolina 29401, USA \\ ${ }^{2}$ University of South Carolina, Columbia, South Carolina 29208, USA \\ ${ }^{3}$ Coastal Carolina University, Conway, South Carolina 29528, USA \\ ${ }^{4}$ South Carolina Department of Natural Resources, Charleston, South Carolina 29412, USA
}

\begin{abstract}
Hypoxic episodes in the shallow nearshore waters of Long Bay, South Carolina, USA, an open coast embayment on the South Atlantic Bight, have been observed on a number of occasions during the summer months from 2004 to 2009, with the most pronounced ones occurring in July of 2004 and August and September of 2009. We present a synthesis of data that included time-series oxygen measurements, synoptic surveys of water quality and oxygen consumption rates, and circulation numerical modeling aimed at explaining these hypoxic events. Periods of hypoxia coincide with coastal upwelling conditions (i.e. winds from the southwest and colder bottom waters). Field flow data and numerical simulations confirmed that these conditions create onshore-directed bottom flows. The latter also showed that this onshore water intrusion can penetrate into very shallow waters (5 to $7 \mathrm{~m}$ depth) and is separated from the very shallow waters by a mixing front. Nutrient and organic matter concentrations, especially the particulate forms, were higher in the nearshore ( 0.3 km from the coastline) compared to offshore (2 to $3 \mathrm{~km}$ from the coastline) waters, while dissolved oxygen concentrations tended to increase with distance from shore. Oxygen consumption rates via water-column respiration were highly variable (5.6 to $73.6 \mu \mathrm{g} \mathrm{O}_{2} \mathrm{l}^{-1} \mathrm{~h}^{-1}$ ), but showed significant correlations with spatial variability in particulate nutrient and organic matter concentrations. These observational and modeling results suggest that occurrences of low dissolved oxygen in Long Bay result from regional oceanographic processes that constrain water masses to the nearshore and thus prevent the wider dispersion of local terrestrial inputs. The resulting enhanced material concentrations stimulate heterotrophic oxygen demand, leading to hypoxia in the immediate nearshore waters.
\end{abstract}

KEY WORDS: Nearshore hypoxia · Upwelling · Respiration · Eutrophication · South Atlantic Bight

Resale or republication not permitted without written consent of the publisher

\section{INTRODUCTION}

Coastal hypoxia, defined as the depletion of dissolved oxygen (DO) to concentrations $<2 \mathrm{mg} \mathrm{O}_{2} \mathrm{l}^{-1}$, has been increasing in frequency, duration, and extent worldwide over the last 5 decades (Diaz \& Rosenberg 1995, Wu 2002, Chan et al. 2006, Hawley et al. 2006, Diaz \& Rosenberg 2008). In addition, coastal marine ecosystems tend to exhibit thresholds whereby repeated occurrences of hypoxic events promote an increased susceptibility of further prolonged hypoxia and accelerated eutrophication (Conley et al. 2009). Hypoxic events can significantly impact biological communities in the coastal ocean 
(Boesch \& Rabalais 1991), and the impact of low DO on sediment diagenesis and nutrient biogeochemistry can alter and further exacerbate nutrient conditions in coastal waters (Kemp et al. 2005). Negative economic effects resulting from recurring hypoxia, especially with respect to recreational or commercial fisheries, can be substantial (Diaz \& Solow 1999).

It is clear from previous studies of coastal hypoxia that low DO results from an interaction between physical and biogeochemical processes. Increased prevalence of coastal hypoxia is most often the result of increased production of organic matter associated with excessive nutrient input (Rabalais et al. 2010). Depending on the physical processes, such as stratification and mixing, this increased organic loading alters the balance between oxygen supply through physical forcing and oxygen consumption from organic matter decomposition. Thus, in the absence of stratification, or in the presence of intense mixing, hypoxia is not generally expected to occur, regardless of organic matter loading rates (Conley et al. 2009, although see Verity et al. 2006). As a result of this interplay between physical and biogeochemical processes, hypoxic events have been reported for a variety of coastal settings, ranging from regions with narrow continental shelves such as that of the west coast of the USA (e.g. Grantham et al. 2004, Chan et al. 2006, Connolly et al. 2010), shallow shelves influenced by river discharge such as the Gulf of Mexico (e.g. Wiseman et al. 1997, Turner et al. 2006, Bianchi et al. 2010), enclosed basins such as the Chesapeake Bay and Long Island Sound (e.g. Anderson \& Taylor 2001, Hagy et al. 2004), and shallow continental shelves influenced by bottom bathymetry such as the New Jersey Shelf (e.g. Glenn et al. 1996, 2004). Zhang et al. (2010) suggested a classification of coastal systems based on the location and mechanisms responsible for the generation of hypoxic conditions. These are (1) 'coastal upwelling systems', driven by physical transport of deep bottom water high in nutrients and low in DO to inshore waters; (2) 'off river mouths and in estuaries', driven by nutrient input from land sources and water-column stratification; and (3) 'semi-enclosed seas and basins', driven by land-derived nutrient inputs and watercolumn stratification in combination with restricted physical exchange that promotes long water residence times.

Few cases of hypoxia have been observed for shallow coastal ocean environments such as those along the open-ocean, shallow shelf, coastal region off of South Carolina, USA, where hypoxia was first quan- titatively observed in 2004 (Sanger et al. 2010). At this time, hypoxic conditions were found in the nearshore waters (5 to $7 \mathrm{~m}$ depth) off an open beach in the central portion of Long Bay. That hypoxia occurred just seaward of the surf zone $(\sim 0.3 \mathrm{~km}$ from the beach-face) was somewhat surprising, given this is an area generally considered to experience high physical mixing. Analysis of limited water quality and meteorological data revealed that the first documented hypoxic event occurred during a period of sustained southwesterly upwelling-favorable winds that coincided with the occurrence of cold bottom water (Sanger et al. 2010). Although Long Bay is influenced by coastal upwelling, no evidence existed to suggest that the upwelled water was a direct source of high nutrients or low DO. In addition, the location is not adjacent a major river source and the adjacent estuaries of Winyah Bay in the south and Cape Fear in the north do not discharge large amounts of water during the summer (McCarneyCastle et al. 2010), and no evidence of surface-buoyant plumes has been reported. The region is, however, subject to significant diffuse pollution from the Greater Myrtle Beach area, a highly urbanized ocean-front resort community. Given the shape of the coastline, Long Bay cannot be considered a semienclosed sea or basin, nor is it close to the continental slope. As such, it cannot easily be classified as any of the 3 system types for hypoxia formation. Instead, it seems that hypoxia formation in the central region of Long Bay results from a unique combination of physical and biological mechanisms that are a mixture of the 3 types of systems identified by Zhang et al. (2010).

Following the initial observation of hypoxia in the summer of 2004, a multidisciplinary team of scientists and managers from a variety of academic, state, and federal institutions was assembled to investigate the potential cause of hypoxia in Long Bay (Sanger et al. 2010). Several alternative mechanisms or hypotheses for hypoxia generation were proposed at that time, based on experiences from well-known hypoxic events elsewhere (Sanger et al. 2010). This then led to a variety of research and monitoring activities 2006 to 2008, with the goal of further documenting and understanding the occurrence of hypoxia in this shallow open-coast environment. The objective of our paper is to synthesize the data from these efforts relating to the formation of hypoxic conditions in the nearshore waters of Long Bay and assess the contributions of oceanographic and biogeochemical processes in promoting hypoxia in this region. 

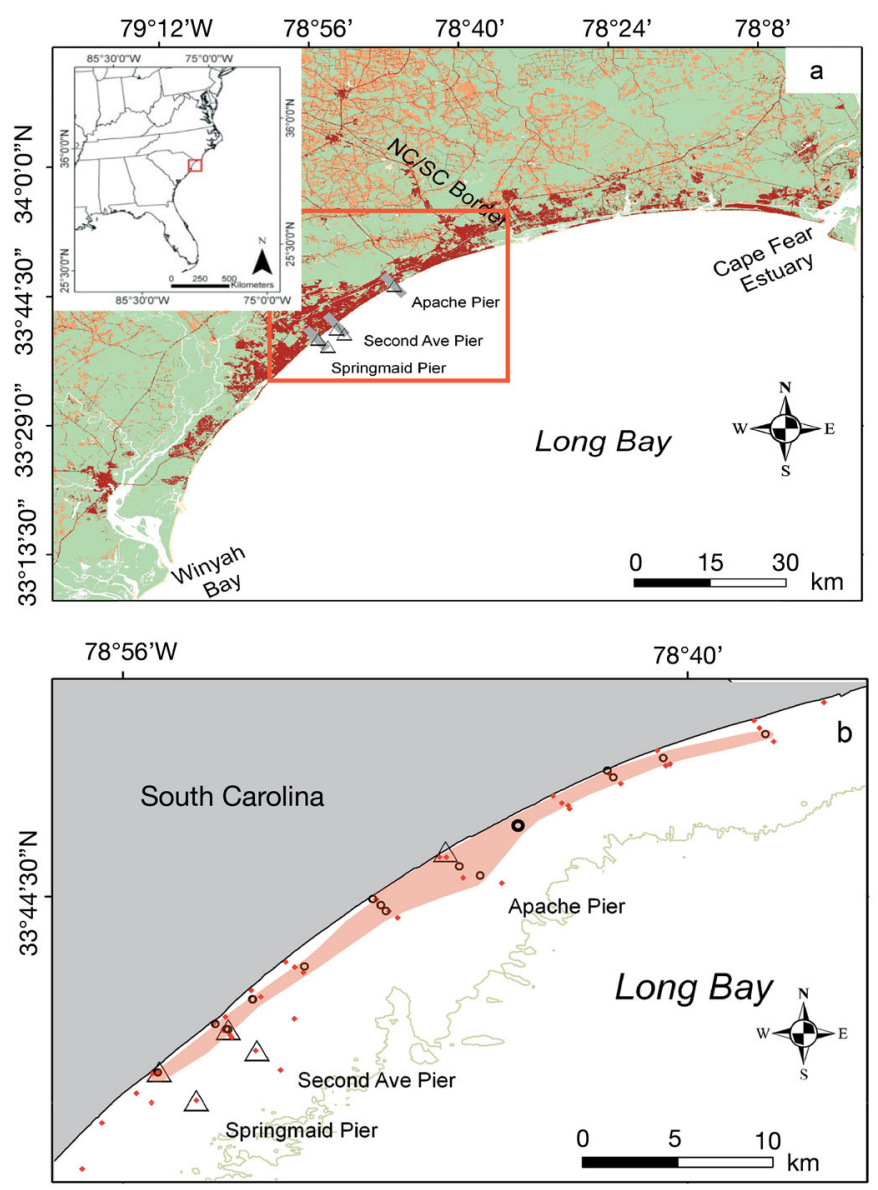

Fig. 1. (a) Long Bay region USA, with (b) the general area (pink) over which hypoxia was observed at some point during August of 2009. Monitoring sites near Apache, Second Avenue, and Springmaid Piers are identified with triangles. Red points and open circles in (b) are sites where measured bottom dissolved oxygen concentrations were $>2$ and $<2 \mathrm{mg}$ $\mathrm{O}_{2} \mathrm{l}^{-1}$, respectively, during the August 2009 event. Note: 5 sites to the south are not shown but were $>2 \mathrm{mg} \mathrm{O}_{2} \mathrm{l}^{-1}$. (a) Long Bay land use data — red: developed land; green: forested and wetlands; orange: agriculture (NOAA Coastal Change Analysis Program 2005). Green line in (b) shows the $10 \mathrm{~m}$ isobath according to the NOAA Geophysical Data Center

\section{MATERIALS AND METHODS}

\section{Study area}

Long Bay, an open-ocean, shallow embayment on the South Atlantic Bight (SAB) of the USA, extends for $145 \mathrm{~km}$ from the Cape Fear Estuary, North Carolina, in the north, to Winyah Bay, South Carolina, in the south, which are the 2 main riverine sources (Fig. 1). The shoreline along the central portion of Long Bay includes the urbanized beach-front resort community of Greater Myrtle Beach, South Carolina ( $\sim 57 \mathrm{~km}$ of shoreline). This area, with a resident pop- ulation of 300000 (based on 2008 United States census data), receives $\sim 14$ million visitors per year with $90 \%$ visiting the beach (MBCC 2009). Tourism accounts for $\$ 3.1$ billion or $31.6 \%$ of the state's total domestic travel expenditures (US Travel Association 2009). Storm-water runoff from Greater Myrtle Beach is discharged directly into nearshore waters via 14 anthropogenically modified tidal creeks that traverse the beach face and 100 storm-water discharge outlets (ocean and beach-front outfall pipes). Together these outlets drain a highly urbanized landscape that includes a large network of storm-water detention ponds.

\section{Data availability}

Following the initial observation of hypoxia in Long Bay, several individual research projects were initiated and carried out during the period from 2006 to 2008. In addition, a program of continuous monitoring of DO in surface and bottom waters at a central location in the nearshore waters off Greater Myrtle Beach was established. Although episodes of depressed DO $\left(<4 \mathrm{mg} \mathrm{O}_{2} \mathrm{l}^{-1}\right)$ often occurred during the summer months of this period, no sustained hypoxic periods similar to the 2004 event were observed. During the summer of 2009, however, sustained hypoxia with periods of anoxia was observed (Libes \& Kindelberger 2010, McCoy et al. 2011), suggesting that the 2004 event was not an isolated incident. In response to this event, an ad hoc effort was conducted to gather as much information about the event as possible despite limited resources available at the time. Data available from the planned research from 2006 to 2008 and from the rapid response to the 2009 event are described in the following sections and broadly categorized as continuous monitoring, targeted research, and response sampling to the 2009 events.

\section{Continuous oxygen monitoring}

At the north end of Greater Myrtle Beach, near the northern limit of the low DO observations made in July of 2004, a continuous monitoring station was established in June of 2006. The station consists of 2 sondes (Yellow Springs Instruments [YSI] 600R with Clark DO cells) installed at the seaward end of a fishing pier (Apache Pier, located at $33.7615^{\circ} \mathrm{N}$, $78.7798^{\circ} \mathrm{W}$ ) at a mean water depth of $7 \mathrm{~m}$. The sensors were placed in perforated PVC standpipe painted with antifouling paint and provided mea- 
surements of DO, temperature, and conductivity at 15 min intervals at the surface $(\sim 1 \mathrm{~m}$ below the instantaneous sea level) and at $1.5 \mathrm{~m}$ above the sea bed. The performance of the sensors and data quality was validated through pre- and post-deployment calibration checks and by comparison with in situ measurements made with other instruments. Measurement uncertainties were $\pm 0.4 \mathrm{psu}_{1} \pm 0.4 \mathrm{mg} \mathrm{O}_{2}$ $\mathrm{l}^{-1}, \pm 5 \%$, and $\pm 0.1^{\circ} \mathrm{C}$, for salinity, DO concentration, percent DO saturation, and water temperature, respectively.

\section{Hypoxia research projects}

Two targeted research projects were undertaken during the period from 2006 to 2008: (1) field sampling of inner shelf waters ( 0.3 to $3.0 \mathrm{~km}$ from shore) for water-column oxygen consumption rates and biogeochemical conditions associated with occurrences of low oxygen waters and (2) numerical simulation modeling of physical scenarios under which Gulf Stream Water (GSW) can reach nearshore in Long Bay. The first project was aimed at quantifying the potential for local biogeochemical conditions to drive in situ depletion of oxygen through enhanced pelagic respiration (local forcing of low DO conditions), while the second project was aimed at the hypothesis that the hypoxia is the result of the advection of deep, cold GSW that may be rich in nutrients and low in oxygen concentration (remote forcing of low DO conditions).

\section{Biogeochemistry and pelagic respiration}

To understand the relationships between nearshore and offshore distributions of DO, chlorophyll, nutrients, organic matter, and DO consumption due to pelagic respiration, a series of sampling excursions were conducted during the summers of 2006 (10 to 11 July 2006, 27 to 28 July 2006, 7 to 8 August 2006, 24 to 25 August 2006), 2007 (24 to 25 July 2007, 15 August 2007), and 2008 (11 July 2008, 25 July 2008, 29 August 2008). Sampling focused on dates with spring tidal conditions $( \pm 3 \mathrm{~d})$ and low slack tidal stages $( \pm 2.5 \mathrm{~h})$. For each date, 2 to 3 shoreperpendicular transects were sampled running between 0.3 and $3.0 \mathrm{~km}$ from shore. The transects were located off sites suspected of being influenced by land-based stormwater contributions (i.e. tidal creeks), as well as sites away from such influences, with all transects confined in the region between
Apache and Springmaid Piers (Fig. 1). Along each transect, DO and chlorophyll a (chl a) were routinely sampled in surface and bottom waters using a YSI 85 DO sensor and WETLABS fluorometer, respectively. The fluorometer was calibrated using independently collected acetone-extracted chl a samples that were quantified by bench-top fluorometry (Arar \& Collins 1997). In addition, water samples were collected from the surface and bottom waters, using a Van Dorn sampler, from the 0.3 and $3.0 \mathrm{~km}$ sites of each transect, hereafter referred to as nearshore and offshore sites, respectively. Samples were stored on ice until returned to the laboratory for processing.

Water samples were analyzed for total nitrogen (TN) (whole [TNW] and filtered [TNF]), total phosphorus (TP) (whole [TPW] and filtered [TPF]), orthophosphate, nitrate + nitrite, ammonium, particulate organic matter (POM), dissolved organic carbon (DOC), chl $a$, and pheophytin (pheo). TN, TP, orthophosphate, nitrate + nitrite, and ammonium were measured using seawater methods for a Technicon nutrient autoanalyzer, with working ranges suitable for coastal waters. The TN and TP method was based on dual persulfate digestion (Glibert et al. 1977). The particulate components of the total nitrogen $\left(\mathrm{TN}_{\mathrm{part}}\right)$ and total phosphorus ( $\mathrm{TP}_{\text {part }}$ ) were determined by subtraction of the whole minus the filtered components. Dissolved organic nitrogen (DON) and phosphorus (DOP) were calculated by difference. Total suspended sediment (TSS) concentrations were determined by standard gravimetric methods, with the organic fraction of TSS (hereafter referred to as POM) determined by loss on ignition at $450^{\circ} \mathrm{C}$. DOC concentrations were determined on filtered $(\mathrm{GF} / \mathrm{F})$, acidified water samples by high-temperature combustion using a Shimadzu TOC-VCPN following the procedures of Benner \& Strom (1993). Phytoplankton pigments were analyzed via acetone extraction for chl $a$ and pheo and quantified by fluorometry (Arar \& Collins 1997).

A subset of water samples collected for the above analyses were subjected to microplankton respiration rate measurements. These samples were maintained at in situ temperatures during transport $(<4 \mathrm{~h})$ to the laboratory, where incubations were conducted. Respiration rates were determined from standard dark-bottle oxygen consumption rates during $6 \mathrm{~h}$ incubations in $300 \mathrm{ml}$ borosilicate glass biochemical oxygen demand (BOD) bottles (e.g. Smith \& Kemp 2001). Oxygen concentrations were determined by automated Winkler titrations of whole bottle samples using a Metrohm 798 Titrino with potentiometric end-point detection (Carignan et al. 1998). Tempera- 
tures during incubation were maintained at $\pm 1{ }^{\circ} \mathrm{C}$ of in situ temperatures, which ranged from 26 to $28^{\circ} \mathrm{C}$ for all sampling events.

\section{Numerical simulation model}

Previous research in the SAB has shown that it is not uncommon for cold GSW to be present in the outer shelf bottom layer during the summer season (Atkinson \& Blanton 1986, Lee \& Pietrafesa 1987, Hamilton 1987). Once the GSW is present on the outer-shelf, upwelling-favorable southwesterly winds, common in the summer (Blanton et al. 2003), can transport it across the shelf (Hoffmann et al. 1980, 1981), with the occurrence of GSW on the middle shelf not being unusual. Such events had been identified in Long Bay from the analysis of salinity-temperature data (T-S diagrams) from a data buoy located at $10 \mathrm{~m}$ water depth (Voulgaris \& Sanay 2010). These observations led to the development of the hypothesis that GSW intrusions might be associated with the observed hypoxic events. In order to identify the physical scenarios under which GSW intrusions can reach the inner-shelf and the relative importance of each forcing mechanism, a series of process-oriented 3-D numerical simulations were carried out.

The numerical model used was the regional ocean model system (ROMS), a primitive equation, free-surface, hydrostatic, sigma-coordinate model (Shchepetkin \& McWilliams 2005). The model setup included all the terms of the primitive equations except horizontal viscosity (Haidvogel et al. 2000, Umlauf \& Burchard 2003). The model domain (Sanay et al. 2008, Voulgaris \& Sanay 2010) was set up to simulate a concave-shaped bay (300 km long) bounded by Cape Fear (in the north) and Cape Romain (in the south). The characteristics of the central part of the domain resemble the morphological and bathymetric features of Long Bay from the coast (5 $\mathrm{m}$ depth) to $\sim 150 \mathrm{~km}$ offshore (55 $\mathrm{m}$ depth). In both horizontal directions, the grid resolution varied from 1.5 to $3 \mathrm{~km}$, with the highest resolution near the coast.

Several numerical simulations were carried out to elucidate the physical conditions under which GSW can reach the inner-shelf. The direction, magnitude, and duration of the wind patterns used in the simulations were consistent with those observed in this section of the SAB during summer (Blanton et al. 2003). The initial conditions used included (1) well-mixed conditions and (2) an initial vertical stratification con- sisting of a well-mixed surface layer $\left(4 \mathrm{~m}\right.$ thick, $22^{\circ} \mathrm{C}$ ) and a bottom layer $\left(15^{\circ} \mathrm{C}\right)$ with a linearly stratified thermocline density in between extending from 4 to $10 \mathrm{~m}$ below the surface, resembling typical summer stratification conditions in the SAB (Aretxabaleta et al. 2006). Each of the initial conditions presented above were forced with (1) constant wind stress linearly ramped up to a maximum value of $0.10 \mathrm{~N} \mathrm{~m}^{-2}$ within a period of $6 \mathrm{~h}$ which then remained constant and (2) an oscillatory wind stress with a period of $3 \mathrm{~d}$ and minimum and maximum values of 0.01 and $0.20 \mathrm{~N} \mathrm{~m}^{-2}$, respectively. Each simulation case was carried out with and without solar radiation, resulting in 8 simulation scenarios that combined all the conditions described above. The wind stress levels and periods of oscillations were selected to correspond to the most common atmospheric conditions observed during the hypoxic events of 2004 and in accordance with published wind climatology. Additional simulations were carried out with freshwater discharge inputs of $\sim 350 \mathrm{~m}^{3} \mathrm{~s}^{-1}$ from the north and south boundaries, representing buoyancy fluxes for the Cape Fear and Pee Dee Rivers, respectively.

\section{9 hypoxia event sampling}

With the onset of significant hypoxia observed at the Apache Pier monitoring station in August of 2009, several ad hoc sampling programs were undertaken to resolve the cross-shore (nearshore to offshore) and alongshore extent of hypoxic waters and the physical-chemical conditions associated with these waters. Ship-based spatial surveys of surface $(0.3 \mathrm{~m}$ below water surface) and bottom $(0.5 \mathrm{~m}$ above sediment surface) water DO concentrations and water-column physical properties were conducted on 3 separate dates during the hypoxic period $(20,24$, and $27 \mathrm{Au}-$ gust 2009). Discrete samples were also collected from surface and bottom samples on 20 August 2009 ( $\mathrm{n}=$ 28) and 27 August $2009(n=10)$ at a number of sites both within and outside the observed hypoxic area. These water samples were analyzed in the laboratory for nutrients, organic matter, chl $a$, and pheo, as described previously. Phytoplankton community composition was also determined from $250 \mathrm{ml}$ of water preserved with Lugol's iodine solution diluted to $3 \%$. Phytoplankton identification to the lowest taxonomic level possible was carried out using light microscopy, but this analysis was limited only to samples collected on 20 August 2009.

Flow measurement data were available for the same period from 2 locations at $\sim 0.85 \mathrm{~km}$ ( $7 \mathrm{~m}$ water 
depth) and $2.5 \mathrm{~km}(10 \mathrm{~m}$ water depth) off the shoreline of Second Avenue Pier (Fig. 1, triangles). The nearshore site was instrumented with a high-resolution downward-looking $1200 \mathrm{KHz}$ RDI/Teledyne Acoustic Doppler Current Profiler (ADCP) mounted at $1.5 \mathrm{~m}$ above the seabed and an upward-looking Nortek Acoustic Wave and Current (AWAC) Profiler. The ADCP measurements were limited to the lowest $1 \mathrm{~m}$ of the water column, with a $10 \mathrm{~cm}$ bin size, while the AWAC measured current velocities throughout the entire water column, with a $1 \mathrm{~m}$ bin size from $2 \mathrm{~m}$ above the sea bed to the surface. The offshore site was instrumented with a Sontek Acoustic Doppler Velocimeter (ADV) which measured currents at $15 \mathrm{~cm}$ above the seabed and an upward looking $1200 \mathrm{kHz}$ RDI/Teledyne ADCP measuring directional wave spectra and mean current profiles of the water column in $1 \mathrm{~m}$ bins. The instruments that measured currents within the lower water column at each site collected data simultaneously in 'burst mode' at $1 \mathrm{~Hz}$ for $\sim 17$ min every $2 \mathrm{~h}$. The AWAC and upwardlooking ADCP measured mean current velocities throughout the upper water column every 10 min.

At the onset of hypoxia, the 2 flow measurement sites off Second Avenue Pier were also equipped with YSI 6600 sondes to measure DO, temperature, $\mathrm{pH}$, conductivity, turbidity, and chlorophyll every 15 min from 20 August to 4 September 2009. Additionally, 2 water quality Hydrolab 5 datasondes were deployed in the bottom waters at $\sim 0.25$ and $2.5 \mathrm{~km}$ off Springmaid Pier (Fig. 1, triangles) from 20 August to 4 September 2009.

\section{Statistical analysis}

Statistical analysis of the various water-column metrics (e.g. nutrients, organic matter, respiration rates) included Spearman correlation analysis, principal component analysis (PCA), and regression analysis using the SAS (V9.1) and JMP (V8.0) statistical packages. Spearman correlation and PCA were used to determine the role of substrate regulation in respiration rates. The correlation alpha levels were corrected for multiple comparisons using a Proc MULTTEST Stepdown Bonferroni.

\section{RESULTS}

\section{Dissolved oxygen temporal dynamics}

Time-series DO data from Apache Pier showed both surface and bottom waters of the central portion of nearshore Long Bay waters to be generally undersaturated with respect to DO (Fig. 2). During the summer months (June to September) of 2006, 2007, and 2008, depressed DO levels $\left(<4 \mathrm{mg} \mathrm{O}_{2} \mathrm{l}^{-1}\right)$ were

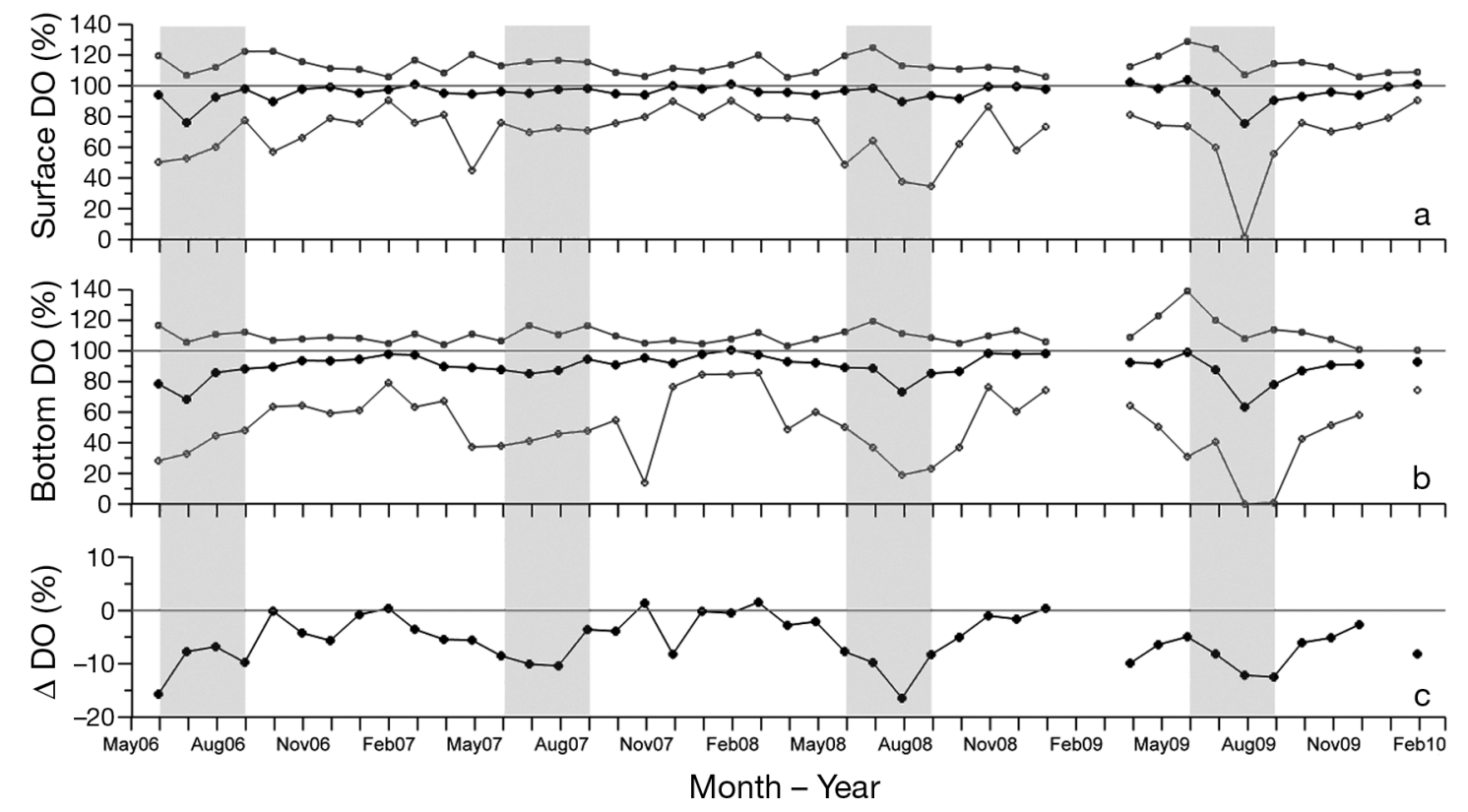

Fig. 2. Time series of dissolved oxygen (DO) saturation levels (monthly mean, maximum, and minimum) near the (a) water surface and (b) sea bed. (c) Difference of the monthly means from the surface to the bed ( $\Delta \mathrm{DO})$. Data from the station located on Apache Pier. Grey shading shows summer months (June to September) 
common in the bottom waters (Fig. 3a). They developed into hypoxic conditions $\left(<2 \mathrm{mg} \mathrm{O}_{2} \mathrm{l}^{-1}\right)$ for some of these periods, but were of short duration (a few hours). Close examination of the wind speed and direction measurements from the Springmaid Pier NOAA station indicated that all of these events coincided with periods of upwelling-favorable winds (Fig. 3c, positive alongshore wind velocity or winds from the southwest). This coincidence of hypoxic conditions along with upwelling-favorable winds implied a strong dependence on physical forcing.

\section{Biogeochemistry and pelagic respiration}

In the summers of 2006 to 2008, nutrient, chl $a$, and POM concentrations tended to significantly co-vary, both within surveys and across years. In contrast, concentrations of DOC showed little spatial or temporal variation and were not significantly correlated to other water chemistry parameters. Across all samples, approximately half the nitrogen and phosphorus pools were found in particulate form, with organic fractions comprising a majority of the total dissolved nitrogen (80 to $90 \%$ ) and phosphorus (40 to $60 \%$ ). On average, nutrient, chl $a$, and organic matter concentrations all decreased from nearshore to offshore sites (Table 1). Pair-wise comparisons revealed these nearshore-offshore differences to be significant $(\mathrm{p}<0.01)$ for all variables except for DOC and the dissolved inorganic nutrients. Similarly, concentrations of particulate nutrients and chl $a$ were significantly greater in bottom waters than in surface waters, but surface-bottom differences were not significant for dissolved nutrient or DOC concentrations.

Table 1. Respiration rate $\left(\mu \mathrm{g} \mathrm{O}_{2} \mathrm{l}^{-1} \mathrm{~h}^{-1}\right)$, chlorophyll a ( $\left.\mathrm{chl} a, \mu g \mathrm{l}^{-1}\right)$, unfiltered total nitrogen (TNW, $\mu \mathrm{mol} \mathrm{l}^{-1}$ ), filtered total nitrogen (TNF, $\mu \mathrm{mol} \mathrm{l}^{-1}$ ), unfiltered total phosphorus (TPW, $\mu \mathrm{mol} \mathrm{l^{-1 }}$ ), filtered total phosphorus $\left(\mathrm{TPF}, \mu \mathrm{mol} \mathrm{l} \mathrm{l}^{-1}\right.$ ), and dissolved organic carbon (DOC, $\mathrm{mg} \mathrm{l}^{-1}$ ) measured during summers of 2006 to 2008. All means, with (SD, n). Respiration rate in surface waters was only measured during 2006

\begin{tabular}{|cccccccc|}
\hline Location & $\begin{array}{c}\text { Respira- } \\
\text { tion rate }\end{array}$ & Chl a & TNW & TNF & TPW & TPF & DOC \\
\hline Nearshore & 19.7 & 4.80 & 17.3 & 12.4 & 0.97 & 0.59 & 2.50 \\
surface & $(3.8,9)$ & $(2.91,49)$ & $(5.4,51)$ & $(3.3,51)$ & $(0.43,51)$ & $(0.14,51)$ & $(0.86,49)$ \\
Nearshore & 25.4 & 8.13 & 19.8 & 12.4 & 1.42 & 0.65 & 2.67 \\
bottom & $(12.2,27)$ & $(5.03,48)$ & $(7.5,50)$ & $(3.1,50)$ & $(0.86,50)$ & $(0.26,50)$ & $(1.50,48)$ \\
Offshore & 13.2 & 2.49 & 14.6 & 11.6 & 0.70 & 0.54 & 2.50 \\
surface & $(8.8,9)$ & $(1.60,30)$ & $(5.0,30)$ & $(3.3,30)$ & $(0.22,30)$ & $(0.14,30)$ & $(0.88,27)$ \\
Offshore & 19.5 & 6.77 & 16.3 & 11.6 & 0.98 & 0.61 & 2.43 \\
bottom & $(9.2,27)$ & $(5.97,31)$ & $(4.9,31)$ & $(2.2,31)$ & $(0.42,31)$ & $(0.14,31)$ & $(0.69,28)$ \\
\hline
\end{tabular}

Rates of pelagic respiration measured during the summer months of 2006 to 2008 were highly variable, both within and across sampling events. For the entire dataset $(\mathrm{n}=72)$, respiration rates ranged from 5.6 to $73.6 \mu \mathrm{O} \mathrm{O}_{2} \mathrm{l}^{-1} \mathrm{~h}^{-1}$ and showed a $\log$-normal distribution, with a mean of $21.2 \mu g \mathrm{O}_{2} \mathrm{l}^{-1} \mathrm{~h}^{-1}$ and a median of $18.3 \mu \mathrm{g} \mathrm{O} \mathrm{I}^{-1} \mathrm{~h}^{-1}$. On average, respiration rates measured in nearshore bottom waters exceeded rates measured in offshore bottom waters $(25.4 \pm 12.2$ [average \pm 1 standard deviation] versus $19.5 \pm 9.2 \mu \mathrm{g} \mathrm{O} \mathrm{O}_{2} \mathrm{l}^{-1} \mathrm{~h}^{-1}$, respectively), and in 15 paired-station comparisons of nearshore and offshore bottom waters along the same longitudinal transects, nearshore respiration rates were significantly higher $(\mathrm{p}<0.01)$ than corresponding offshore rates on 12 occasions. In contrast to this general nearshoreoffshore gradient in respiration rate, differences between surface and bottom water respiration rates (quantified in 2006 only) tended to be smaller. Surface water respiration rates averaged $14.7 \pm 5.3 \mu \mathrm{g} \mathrm{O}_{2}$ $\mathrm{l}^{-1} \mathrm{~h}^{-1}$, compared to $18.9 \pm 15.0 \mu \mathrm{g} \mathrm{O}_{2} \mathrm{l}^{-1} \mathrm{~h}^{-1}$ in bottom water, and bottom water respiration was significantly greater $(\mathrm{p}<0.01)$ than surface water respiration in 10 of 16 paired comparisons.

The lack of substantial temperature variation $\left(<2{ }^{\circ} \mathrm{C}\right)$ across sampling events allowed us to use relationships between respiration rate and in situ nutrient and organic matter concentrations to explore the role of substrate regulation in controlling the magnitude and variability in respiration in its absence. Across all sampling events, rates of respiration were significantly correlated $(\mathrm{p}<0.0025)$ to concentrations of POM, chl $a$, pheo, DOC, TNW, and TPW (Table 2). Concentrations of these substrates showed significant covariation, with the exception of DOC, which was found to not be significantly related to either chl $a$ or pheo. The role of substrates in regulating respiration rates was also explored using PCA (Fig. 4). The first 2 axes explained $73 \%$ of the variability in the dataset, with 50 and $23 \%$ attributed to PC 1 and PC 2, respectively. PC 1 had high positive loadings for all particulate substrate concentrations (POM, chl $a$, and pheo, $\mathrm{TN}_{\text {part, }} \mathrm{TP}_{\text {part }}$ ) and respiration rates, whereas PC 2 had high positive loadings for all of the dissolved substrate constituents (DOC, TNF, TPF) (Fig. 4). The tight grouping of mean factor loadings for respiration, POM, 

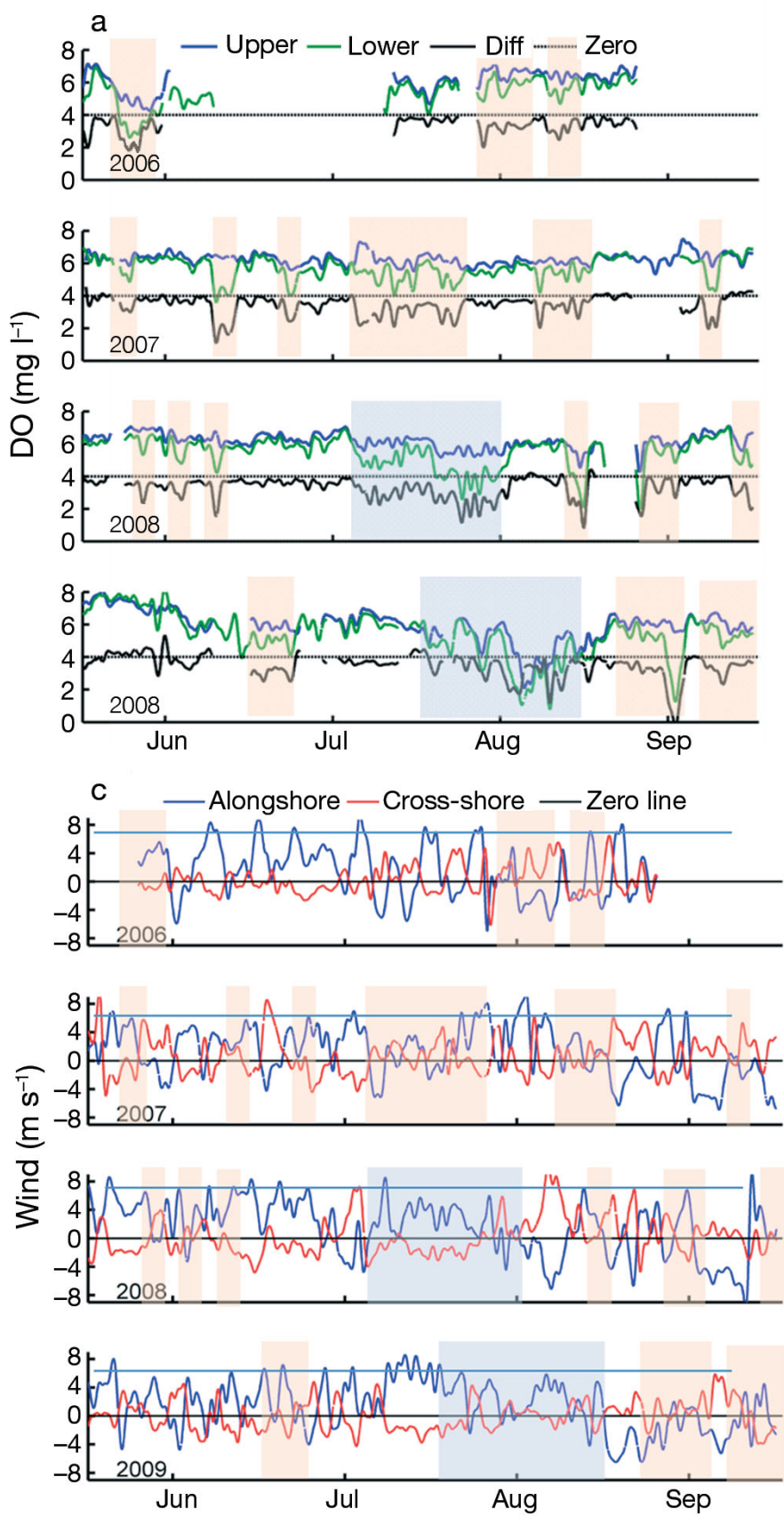

chl a, pheo, $\mathrm{TN}_{\text {part }}$, and $\mathrm{TP}_{\text {part }}$ suggests the importance of living and detrital particulates in determining variability in respiration rates, which is consistent with the fact that POM and chl a were found to have the highest individual correlation coefficients with respiration rate $(0.66$ and 0.70 , respectively) of the entire dataset.

\section{Numerical simulation model}

The results from the numerical modeling work clearly demonstrated the development of a cross-
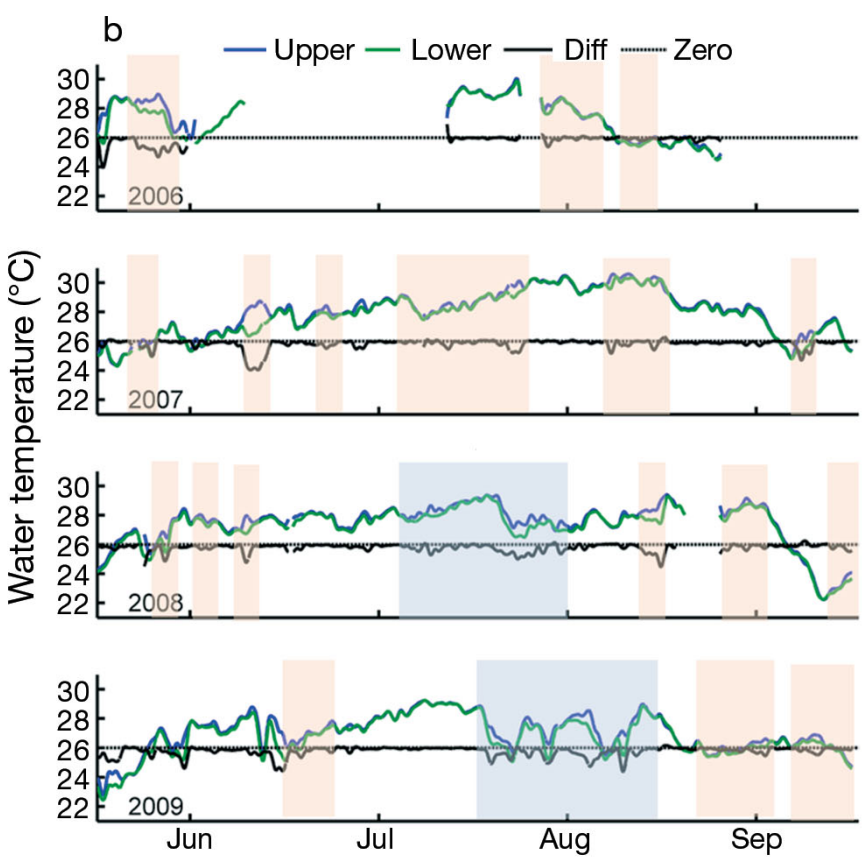

Fig. 3. Low-passed time series of (a) dissolved oxygen (DO) concentration, (b) water temperature, and (c) wind velocity in the surface (upper) and bottom (lower) water column, as well as the difference (Diff) between them (Zero line corresponds to the values for Diff). Pink and blue shaded areas: low oxygen events of short and extended duration, respectively

Table 2. Nonparametric correlation matrix (Spearman's rho value) for respiration rate (resp), particulate organic matter (POM), chlorophyll a (chl a), pheophytin (pheo), dissolved organic carbon (DOC), total nitrogen unfiltered (TNW), and total phosphorus unfiltered (TPW) concentrations. * Statistically significant $(\mathrm{p}<0.01)$ correlations

\begin{tabular}{|lllllll|}
\hline & POM & Chl $a$ & Pheo & DOC & TNW & TPW \\
\hline Resp & $0.661^{*}$ & $0.698^{*}$ & $0.576^{*}$ & $0.558^{*}$ & $0.602^{*}$ & $0.555^{*}$ \\
POM & & $0.724^{*}$ & $0.825^{*}$ & $0.405^{*}$ & $0.745^{*}$ & $0.706^{*}$ \\
Chl $a$ & & & $0.875^{*}$ & 0.191 & $0.488^{*}$ & $0.398^{*}$ \\
Pheo & & & & 0.215 & $0.600^{*}$ & $0.546^{*}$ \\
DOC & & & & & $0.556^{*}$ & $0.474^{*}$ \\
TNW & & & & & $0.841^{*}$ \\
\hline
\end{tabular}

shore circulation (Fig. 5, onshore flow near the bed and offshore-directed flow near the surface in right column) at the outer- and inner-shelf under oscillatory, southwesterly (i.e. upwelling-favorable) wind conditions (Fig. 5, top panel) and under the influence of solar radiation. A few hours after maximum wind stress, the water column near the shoreline (distances $<4 \mathrm{~km}$ ) was homogeneous (Fig. 5, time = $8.0 \mathrm{~d})$. Further offshore, the water column remained stratified and Ekman transport (i.e. offshore-directed flows near the surface) was present. When the mag- 


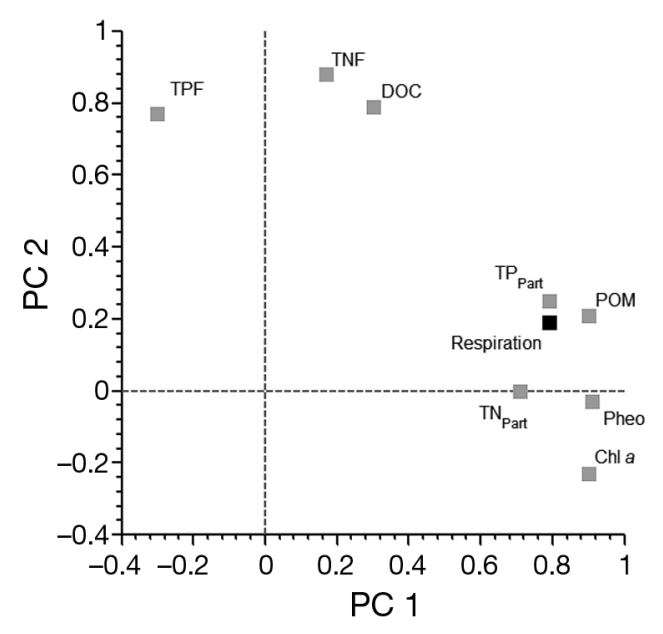

Fig. 4. Principal components (PC) analysis biplot of mean factor loadings on PC 1 and PC 2. Rotated eigenvectors for each parameter are indicated by squares. The PC 1 and PC 2 eigenvalues were 4.5 and 2.1, respectively. The PC 1 and PC 2 percent variability explained by each was 50 and $23.3 \%$, respectively. TPF and TNF: total phosphorus and nitrogen filtered, respectively; $\mathrm{TP}_{\text {part }}$ and $\mathrm{TN}_{\text {part }}$ : particulate components of total phosphorus and nitrogen, respectively; other abbreviations as in Table 2. Respiration ( $\square$ ) clusters with particulate concentrations ( $\square$ )

nitude of the wind stress decreased, the inner-shelf water column began to thermally stratify again due to solar radiation and Ekman transport was re-established in the nearshore (Fig. 5, time $=8.3 \mathrm{~d}$, distances $<4 \mathrm{~km}$ ). This Ekman transport carries cold water toward the coast in the bottom layer and further enhances stratification. As the wind stress increased again, Ekman transport intensified, as well as vertical stratification (Fig. 5, time $=10.0 \mathrm{~d}$ ), until wind stress became strong enough to break the stratification very close to the shoreline and mix the water column, thereby allowing re-oxygenation of the bottom water (Fig. 5, time $=10.3 \mathrm{~d}$ ). The model simulations indicated that during this process, a mixing front developed at the very shoreward end of the domain that defined the area of stratified waters, with onshore-directed bottom flow from a nearshore zone of the well-mixed water column that clearly separated these 2 domains. Model runs under constant upwelling-directed winds of similar strength as the oscillating winds showed no development of Ekman transport due to enhanced mixing. The same results were obtained for oscillating winds, but with no solar radiation included.

The general pattern of flow and temperature conditions provided by the model simulations described above are in close agreement with that observed in Long Bay (water quality at Apache Pier and cur- rent/wind conditions at Springmaid Pier) in the summers of 2006 and 2007 (Fig. 3). In 2006, low-oxygen $\left(<3 \mathrm{mg} \mathrm{O} \mathrm{O}_{2} \mathrm{l}^{-1}\right.$ ) events in the coastal bottom layer occurred only during the summer season (with high solar radiation and low river discharge) and under long periods (>15 d) of upwelling-favorable wind conditions. In contrast, during the summer of 2007 , no periods of low DO were observed near the coast and the water column remained thermally homogeneous most of the time, providing no evidence of thermal stratification (Fig. 3a,b).

\section{9 hypoxic event sampling}

In 2009, a severe hypoxia occurred during the period from 17 to 25 August 2009, followed by a second event during the period from 15 to 17 September 2009 (Fig. 6c). The instantaneously measured DO concentrations varied within each day following a predominantly diurnal cycle mixed with a secondary semidiurnal frequency which led to absolute hypoxic conditions for a significant part of each day (Fig. 6c). Diurnal variability in the instantaneous temperature record was observed, which is explained by solar radiation (Fig. 6b). Examination of the low-frequency variation of the DO concentration shows that this intra-diurnal variability was accompanied by a reduction of the diurnal average over time. This occurred for both surface and bottom signals, with the latter always being lower (Fig. 6d). A similar vertical difference in daily mean water temperatures between surface and bottom waters indicated that thermal stratification had occurred and coincided with the decreases in DO concentration (Fig. 6d).

Sampling showed that this hypoxic event was spatially limited to nearshore waters $(0.25$ to $2 \mathrm{~km}$ offshore) off Greater Myrtle Beach in a fairly cohesive water mass (Figs. $1 \& 7$ ). As with previous events, the 2009 events again coincided with periods of stratification (Fig. 6b,d, vertical differences in water temperature or thermal stratification) and upwellingfavorable wind conditions (Fig. 6a, north, northeastern-directed wind vectors). It is worth noting that the oscillating character of the wind prior to and at the initial stages of each event showed short times of wind reversal followed by consistent upwelling wind vectors, similar to those used in the numerical modeling (Fig. 6a). Furthermore, DO concentrations were also found to increase from nearshore (0.25 to $0.85 \mathrm{~km}$ ) to offshore $(2.5 \mathrm{~km})$ (Fig. $7 \mathrm{a}, \mathrm{b})$. It should be noted that the August event occurred during a period of unusually high astronomic spring tides (Fig. 6e) 

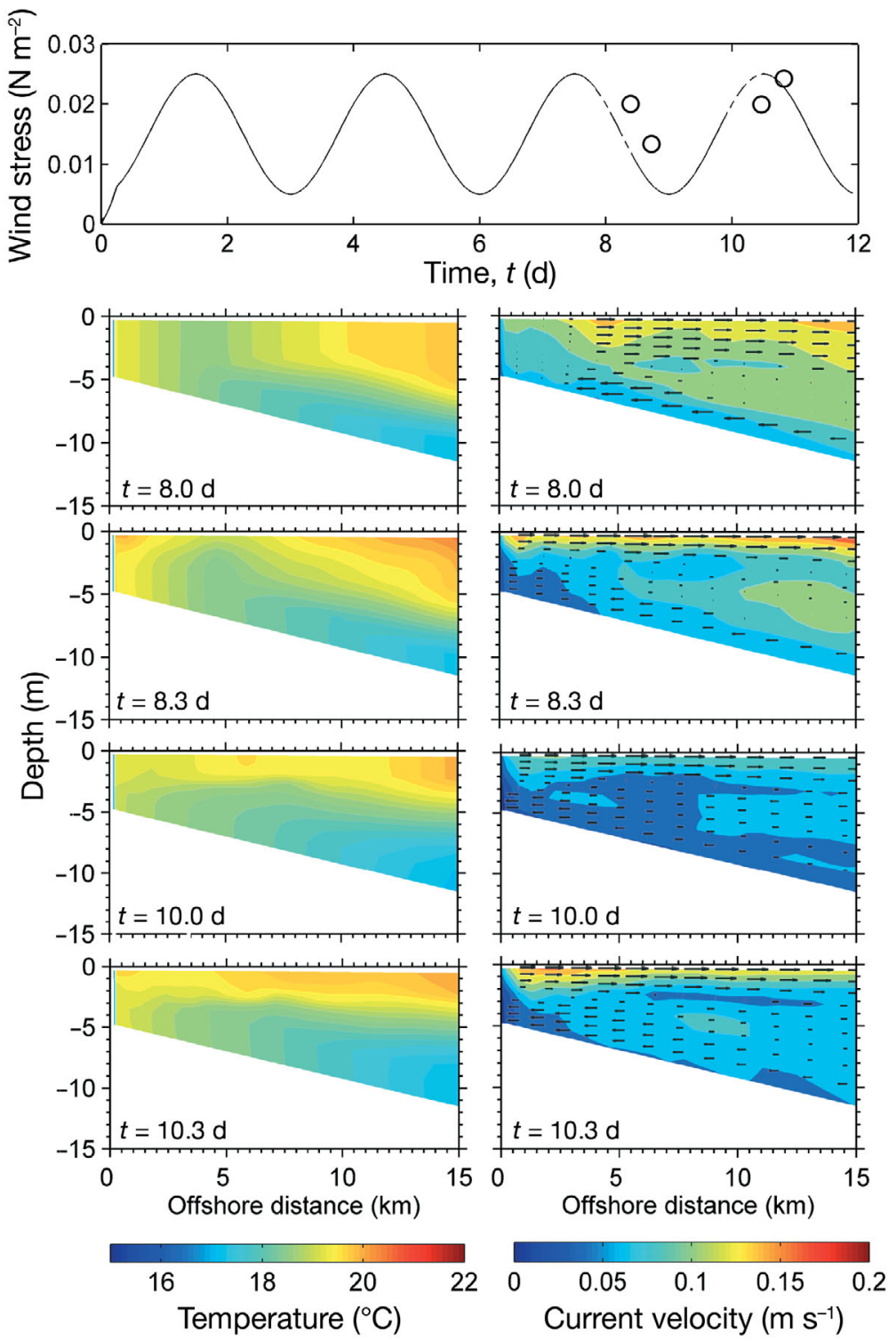

Fig. 5. Sections (views toward the north) of temperature (left panels) and velocity (right panels) fields of the inner-shelf response to wind-driven upwelling at the middle of the bay after 8.0, 8.3, 10.0, and $10.3 \mathrm{~d}$ of simulation. The colors in the velocity field represent the alongshore velocity component, while the vectors represent the cross-shore velocity component. Wind forcing is shown in the upper panel

(Sweet et al. 2009) and this was partially reflected in the bottom DO signal at Apache Pier (Fig. 6c), but was not observed in the signal from the nearshore or offshore stations where the oscillatory signal recorded was mainly diurnal (Fig. 7a,b). Low-passed bottom temperature (Fig. 6d) and cross-shore current velocity data (Fig. 6g) showed a coincidence of lower bottom water temperatures with onshore-directed bottom flows (Fig. 6g, identified by crosses), which indicated that after persistent upwelling-favorable winds, colder bottom water was advected onto the inner-shelf at the 2 Second Avenue Pier locations ( 0.85 and $2.5 \mathrm{~km}$ ). These results follow the flow patterns demonstrated by the numerical model results presented earlier, indicating that a 10 to $15 \mathrm{~d}$ period of upwelling winds could advect GSW to the inner-shelf and nearshore during the summer months when stratification of the water column occurs.

In comparison to the 2006 to 2008 summer data, the August 2009 event was characterized by high concentrations of nutrients, organic matter, and chl $a$. The highest concentrations coincided with the lowest DO levels. Average total nitrogen and total phosphorus (whole and filtered) values in August of 2009 were at least double those observed during the 2006 to 2008 sampling (Fig. 8), although the proportions of total nutrients represented by the particulate fraction were generally similar. Furthermore, station-averaged concentrations of POM and chl a were also more than twice the averages observed during 2006 to 2008 (Fig. 8). Concentrations of DOC measured in 2009 were only slightly higher than concentrations measured during 2006 to 2008 (Fig. 8). Phytoplankton community composition was assessed on 20 August 2009 and was found to be largely composed of Proboscia alata, a large, surface-mat-forming diatom. Concentrations $\left(\sim 5 \times 10^{5}\right.$ to $1 \times 10^{6}{\left.\text { cells } ~^{-1}\right)}^{-}$ were higher in bottom water, suggesting the senescence of $P$. alata cells.

\section{DISCUSSION}

Low DO directly off the beach of an open coastline, away from immediate riverine discharge, would not be expected from the traditional conceptual models of hypoxia development (Rabalais et al. 2010, Zhang et al. 2010). The various observations and results presented in the current paper lead us to conclude that low DO events in Long Bay are, instead, caused by a rather unique combination of regional- and local-scale drivers. The regional-scale drivers are mainly physical oceanographic processes and are associated with upwelling and solar radiation. These physical processes act to concentrate local- 

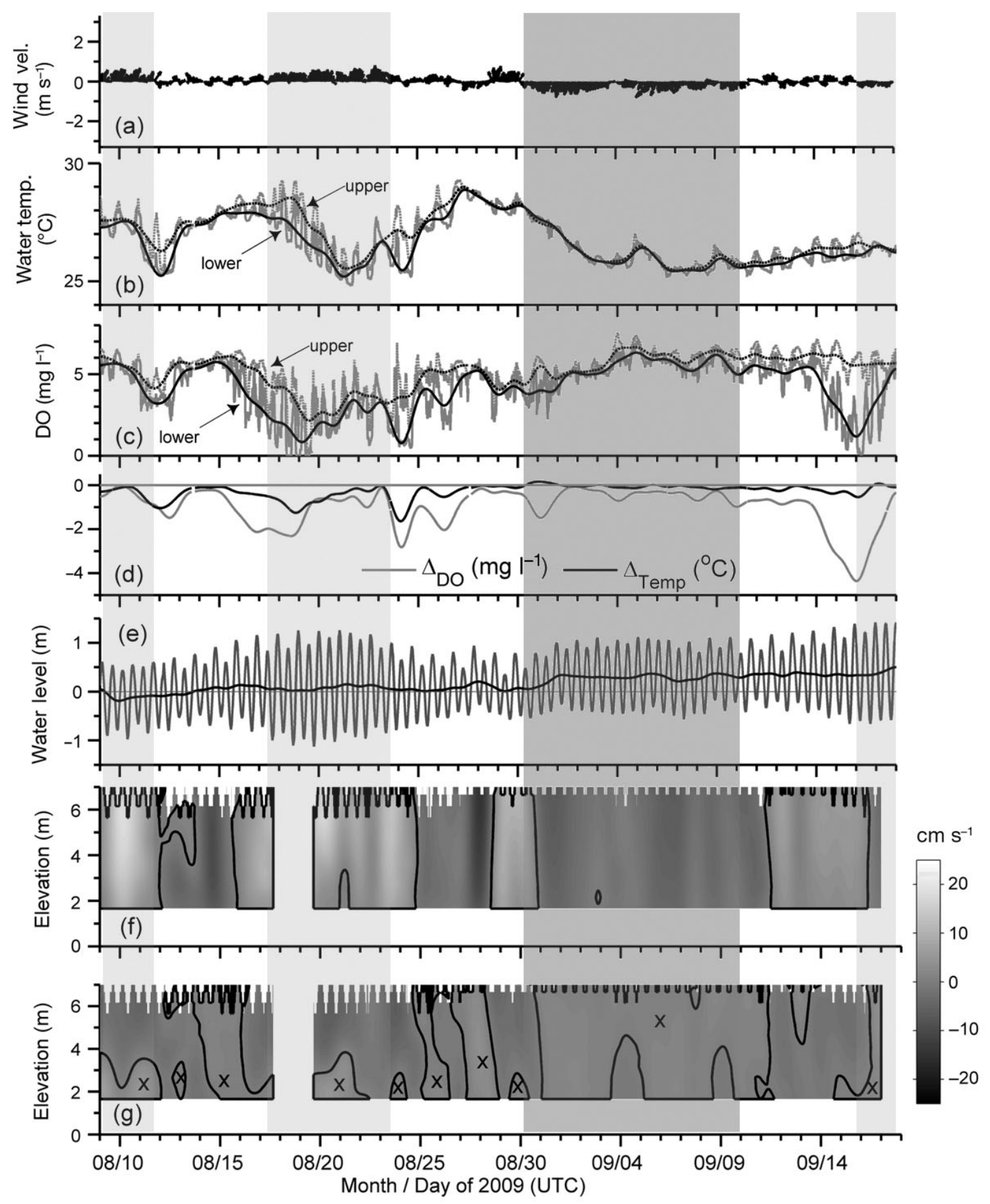

Fig. 6. Meteorological and water-quality time series in Long Bay for the period 8 August to 19 September 2009, showing the correlation of low dissolved oxygen (DO) events with upwelling conditions, including (a) vector diagram of wind velocity (oceanographic convention), (b) instantaneous (grey lines) and low-passed (33 h cut-off, black lines) water temperature at the upper (surface) and lower (bottom) water levels, (c) instantaneous (grey lines) and low-passed (black lines) DO concentration at the upper and lower levels in the water column, (d) difference of low-passed DO concentration (grey line) and temperature (black line) between upper and lower levels (negative values indicate lower values in sensor closer to the sea bed), (e) tidal and mean water level variability, (f) low-passed alongshore vertical structure of water flow measured at the offshore station (positive values shown in light grey colors indicate flow toward the northeast), and ( $g$ ) low-passed cross-shore flow at the same offshore station (positive values indicate onshore flow, denoted by crosses). The contour lines in (f) and (g) represent zero velocity. Vertical shading: periods of (I) consistent upwelling-favorable (light grey), (II) oscillating upwelling (white) and (III) downwelling-favorable (dark grey) winds. Meteorological and tidal elevation data were collected at Springmaid Pier (NOAA, NDBC, and NOS stations MROS1 and 8661070). Water-quality data were collected at Apache Pier. Coastline orientation is 

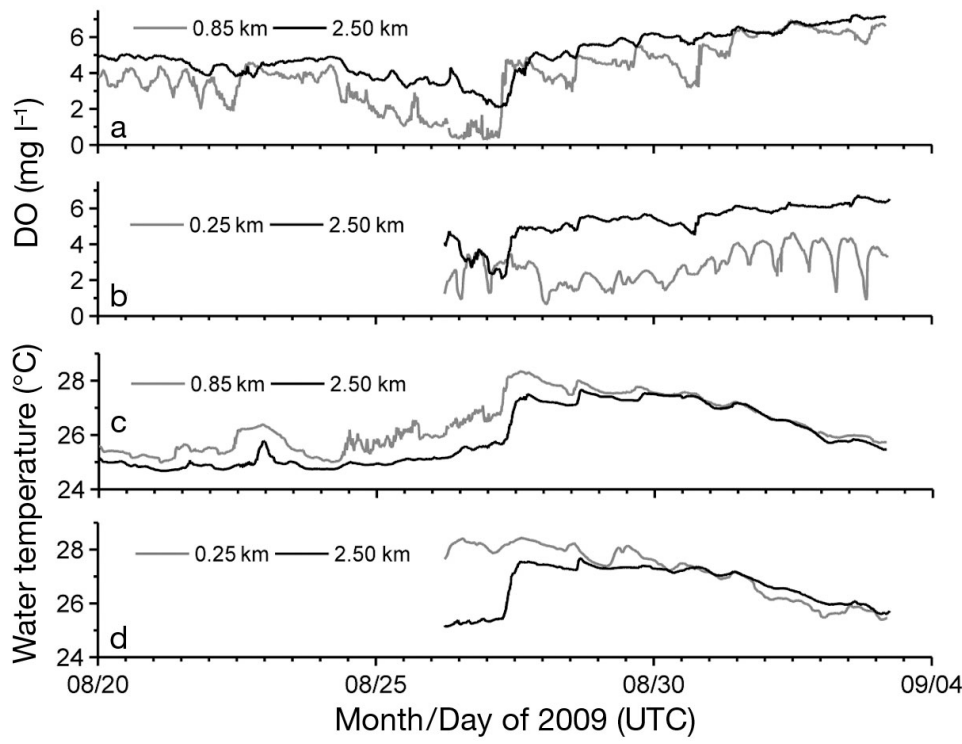

Fig. 7. Time series in Long Bay for the period from 20 August to 4 September 2009 showing the dissolved oxygen (DO) and temperature off Second Avenue $(\mathrm{a}, \mathrm{c})$ and Springmaid Piers $(\mathrm{b}, \mathrm{d})$. Two sites were sampled off Second Avenue Pier at 0.85 and $2.5 \mathrm{~km}$, and 2 sites were sample off Springmaid Pier at 0.25 and $2.5 \mathrm{~km}$ scale (terrestrial) inputs of nutrient and organic matter in the immediate nearshore waters, which greatly enhances localized heterotrophic metabolism and consequent oxygen demand, resulting in formation of low DO conditions in these waters.

The numerical simulations conducted as part of the present study indicate that southwesterly wind conditions can transport offshore water masses all the way to the inner shelf (Fig. 5), which is in agreement with previous studies that have shown these winds can force coastal upwelling along the continental shelf of the southeastern USA (Atkinson 1985, Gutierrez et al. 2006). The magnitude of the intrusion depends on the characteristics (i.e. intensity and duration) of the southwesterly wind events. The cross-shore advective scales of the cold water on the inner-shelf (e.g. distance from the shore) depend on prevailing stratification (Aretxabaleta et al. 2006) as this inhibits water-column mixing. During the summer months, thermal stratification is promoted by intense solar radiation which
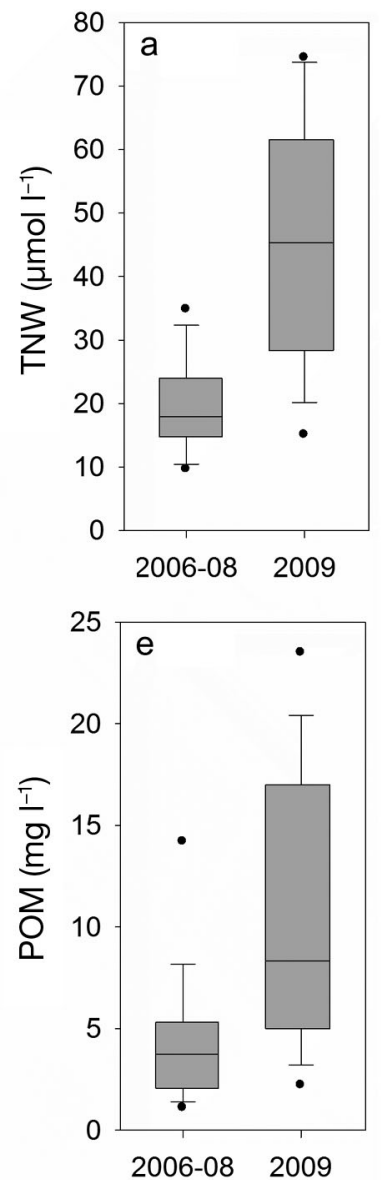
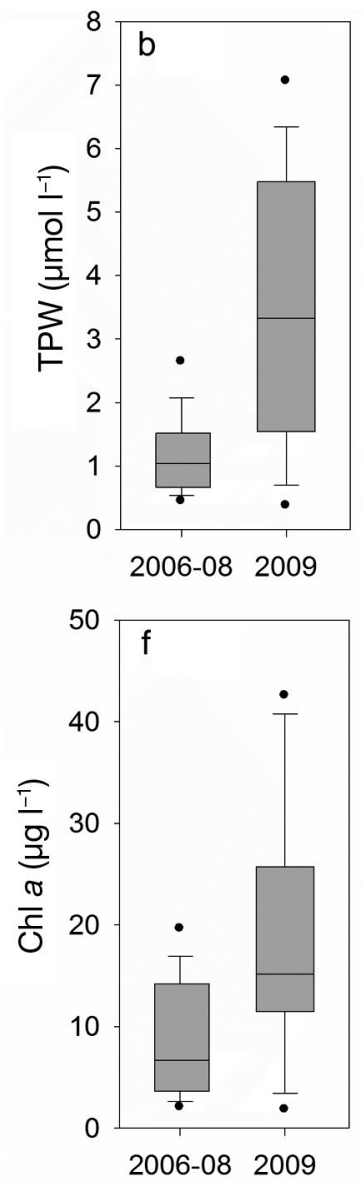
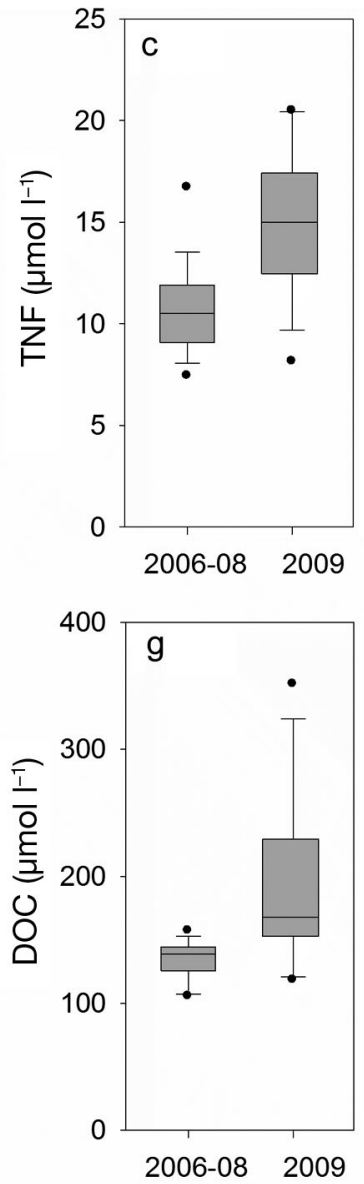

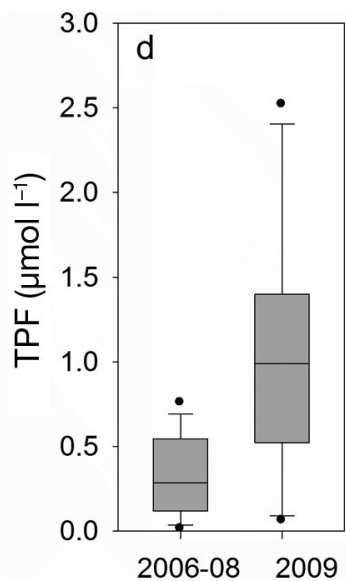

Fig. 8. Bottom water concentrations of (a) total nitrogen unfiltered (TNW), (b) total phosphorus unfiltered (TPW), (c) total nitrogen filtered (TNF), (d) total phosphorus filtered (TPF), (e) particulate organic matter (POM) as estimated on loss of ignition, (f) chlorophyll a (chl a), (g) dissolved organic carbon (DOC) for the summer nearshore 2006 to 2008 sampling events and the August 2009 sampling event. The box and whisker plots show the median (line), 25 and $75 \%$ (box), 10 and $90 \%$ (error bars), and maximum and minimum (points) values 
is continuously maintained since the moderate intensity of the prevailing wind stress inhibits intense water-column mixing (i.e. moderate wind speed and oscillating strength; Fig. 6a). This is intensified by the development of upwelling circulation from southwesterly wind forcing which promotes an alongshore front or barrier to lateral mixing of the very nearshore water with the offshore water (Fig. 5). It is worth noting that this mechanism does not operate on a tidal frequency, the only exception was the August 2009 event where some tidal signal was observed which was likely due to coincidence of this event with the astronomically high tides observed during this period. However, this tidal signal appears to be of secondary importance, as the subtidal levels dominate the signal (Fig. 6c), and it might be associated more with a lateral movement of the front as a function of the highly variable water depth, as has been suggested by McCoy et al. (2011), or with changes in vertical mixing induced by large changes in water depth, or a combination of both.

The association of wind-driven upwelling and bottom water DO conditions predicted by the numerical simulations could best be seen in the 2009 data. In the September 2009 event, hypoxic conditions persisted while the wind was predominately from the southwest, with small oscillatory periods (Fig. 6a,c, 12 to 16 September). The DO concentrations increased when the wind direction changed, relaxing the upwelling conditions which led to a remixing of the water column, both surface to bottom and nearshore to offshore (Fig. 6a,c, 16 to 18 September). During the August 2009 event, the wind direction did not change, but, instead, a slight increase in wind speed and seizing of the initial oscillatory nature of the wind similar to that in the model resulted in the mixing of the water column (Fig. 6a,c). Under persistent wind directions, the ocean continuously gains energy and mixing increases over time allowing this energy to penetrate to larger depths and keeping bottom waters oxygenated.

Although this combination of moderate, oscillatory, upwelling-favorable wind conditions and solar radiation creates the physical pre-conditions necessary for hypoxia development, the lack of evidence of low DO conditions at offshore sites (Fig. 7) indicates that upwelling does not advect a water mass with low DO or high nutrient concentrations from offshore sources, as in typical coastal upwelling systems (Grantham et al. 2004, Zhang et al. 2010). Rather, it appears that the nearshore front of the upwelling system, as identified in the model and 2009 data (Figs. 5 \& 6), provides a barrier or front that limits dispersion and increases the residence time of materials entering the nearshore coastal waters from terrestrial sources (e.g. tidal creeks, stormwater discharge pipes, submarine groundwater discharge). As the model indicates, this front can extend to very shallow waters (up to $5 \mathrm{~m}$, the limit of the model), suggesting a very limited offshore extent of the front. This is further supported by the limited spatial extent of hypoxic water both alongshore $(\sim 50 \mathrm{~km}$ along the length of the coast) and offshore ( 2 km). McCoy et al. (2011) observed greatly elevated radon-222 activities in the nearshore of Long Bay during the August 2009 hypoxia period, which can be explained by the restricted dispersion and trapping of this groundwater tracer in nearshore waters. This observation directly supports the notion that materials were not being mixed out of the nearshore, but, instead, were confined, both surface to bottom by stratification and nearshore to offshore by the upwelling front, in a water mass immediately adjacent to the shoreline.

The importance of terrestrial inputs of nutrient and organic matter substrates is suggested by consistent decreasing material concentrations from nearshore to offshore waters, especially for particulate matter concentrations (Table 1). During the August 2009 hypoxia event, nutrient and organic matter concentrations were substantially elevated relative to mean concentrations measured during previous summers (2006 to 2008) when no significant hypoxia events were observed (Fig. 8). These increases were not uniform, however. The increase in mean POM concentration $(123 \%)$ was much greater than that of DOC $(42 \%)$, but, interestingly, the relative ratio of chl:POM for the 2009 data was essentially identical to that for the 2006 to 2008 data. Examination of precipitation records from the study area revealed no evidence of significant rainfall immediately prior to this event, and no differences in precipitation values between years (except 2007 was a drought year) were found that would result in a significant change in the input of materials into the bay during the August or September 2009 time periods (SC State Climatology Office unpubl. data). This indicates a lack of dispersion of terrestrial materials consistently entering the bay (e.g. via flow from irrigation of urban landscapes, tidal flushing from tidal creeks, groundwater) instead of an episodic influx of new materials. In addition, most of the particulate forms of organic matter and nutrients measured tended to show a high degree of covariation (Table 2), suggesting that upwelling processes simply act to constrain and concentrate all particulate materials equally in the nearshore bottom waters. 
Pelagic respiration rates in Long Bay were both substantial and highly variable. The general pattern of higher rates in nearshore waters compared to offshore waters (Table 1) is consistent with previous observations of respiration in the South Atlantic Bight (Jiang et al. 2010). Respiration rates measured in the present study were much more variable, however, than those reported by Jiang et al. (2010) for innercontinental shelf waters off Georgia in the summers of 2003 to 2006 (20.5 to $28.3 \mu \mathrm{g} \mathrm{O}_{2} \mathrm{l}^{-1} \mathrm{~h}^{-1}$ ) and substantially greater than respiration rates reported for the region of the Gulf of Mexico which is susceptible to hypoxia formation (5.5 to $14.4 \mu \mathrm{g} \mathrm{O}_{2} \mathrm{l}^{-1} \mathrm{~h}^{-1}$; Murrell $\&$ Lehrter 2011). The significant correlations between respiration rates and POM, chl $a, \mathrm{TNW}, \mathrm{TPW}$, and DOC concentrations (Table 2) indicate a strong dependence of heterotrophic metabolism on substrate availability. The fact that these substrates, with the exception of DOC, were themselves significantly correlated makes the use of simple correlation analysis problematic in determining which individual resource most strongly regulated the magnitude of in situ respiration rates in these waters. However, the fact that respiration rate tightly clustered with particulate matter concentrations (Fig. 8) certainly implicates particulate, rather than dissolved, resources in driving enhanced respiration rates under upwelling conditions.

In the majority of hypoxic areas, the organic matter fueling hypoxia is driven by high anthropogenic nutrient inputs stimulating algal blooms that fuel oxygen demand as the bloom collapses and decays (e.g. Pinckney et al. 2001, Conley et al. 2002, Nixon et al. 2008). Although no direct data on primary production rates in this area exist, several lines of evidence suggest that the formation of hypoxia in Long Bay, South Carolina, may not fit this conventional model. The general lack of oxygen supersaturation of the water column during normal conditions, but also immediately preceding the 2009 hypoxia events (Fig. 2), would imply that net heterotrophy predominates in these waters (Verity et al. 2006). While relatively high chl a concentrations have been observed during hypoxic periods, chl a concentrations were always highest in the bottom waters (Table 1) and always strongly correlated with POM concentrations (Table 2) such that chl a:POM ratios remained relatively constant regardless of whether physical conditions promoted upwelling, or not. In addition, a strong inverse relationship has been observed in Long Bay, South Carolina, between DO and chl a during both normoxic and hypoxic periods (Koepfler 2010). These findings can only be explained if heterotrophic metabolism of POM, and its associated oxygen demand, exceeds in situ organic production due to phytoplankton photosynthesis and its associated production of oxygen. Thus, it would appear that microbial respiration leading to hypoxia depends on a source of organic matter other than in situ phytoplankton production. However, the exact source or sources of this organic material remains unclear at present, and further data are clearly necessary to obtain a full understanding of the input and processing of organic material that is driving this ecosystem, especially considering the following 2 observations: (1) the fraction of POM estimated to be represented by phytoplankton (averaged $20.2 \pm$ $11.1 \%$, assuming chl a represents $1.15 \%$ of the ashfree dry weight of organic phytoplankton biomass [Reynolds 2006]) is similar to the fraction typically observed in Chesapeake Bay, a eutrophic system driven by phytoplankton production (Canuel \& Zimmerman 1999) and (2) the observation, at least on one date, of a large mat-forming diatom (Proboscia alata) occurring in high concentrations during the first hypoxic event of 2009.

In summary, hypoxia in Long Bay, South Carolina, appears to occur as the result of regional-scale oceanographic processes limiting cross-shelf dispersion of local-scale terrestrial inputs, which then elevate local organic substrate concentrations that fuel enhanced heterotrophic metabolism and consequent oxygen demand, resulting in the formation of hypoxic conditions in nearshore waters. Such conditions persist until wind conditions change to relax upwelling, which both remixes the water column and allows for wider dispersion of terrestrial inputs, thereby restoring oxygen concentrations and reducing heterotrophic activity due to lowered substrate availability. This interaction between regional-scale physical processes and local-scale ecological processes appears to be a rather unique mechanism of hypoxia formation such that Long Bay does not fall into any of the categories of coastal systems experiencing hypoxia described by Zhang et al. (2010). If worldwide trends are true such that once an area experiences hypoxia, these low DO events tend to become more frequent and intense over time (Conley et al. 2009), we may expect hypoxic conditions in Long Bay to increase, particularly as human population levels are projected to increase, which will likely enhance terrestrial runoff of nutrients and organic matter. We hypothesize that increasing terrestrial loadings associated with continued urban development along the Greater Myrtle Beach area will decrease the physical threshold necessary for the development of hypoxia in Long Bay, and, as such, hypoxic events might affect tourism and, conse- 
quently, the economy of the region. Future research on the relative contributions of loadings from each terrestrial source (e.g. stormwater outfall pipes, tidal creeks, groundwater) is critical before developing potential management actions. In addition, ascertaining the specific threshold levels for hypoxia development in Long Bay will require a better mechanistic understanding of the relative roles played by physical conditions, terrestrial loading, and in situ DO processes in influencing nearshore water quality and DO dynamics.

Acknowledgements. This has been a long-term research effort by numerous collaborators and funded by a variety of sources, including SC Sea Grant Consortium (through NOAA/OAR Grant NA06OAR4170015), SC Department of Natural Resources (through NOAA/NMFS Grant NA04NMF4720306), SC Department of Health and Environmental Control-Office of Ocean and Coastal Resource Management (through NOAA/NOS Cooperative Agreements NA04NOS4190057 and NA06NOS4190193, and FY2008 state supplemental appropriation), National Science Foundation (NSF) awards to University of South Carolina (NSF Awards OCE-0451989 and OCE-0535893), University of South Carolina, Coastal Carolina University, North InletWinyah Bay National Estuarine Research Reserve, and Apache Pier Campground. This is Marine Resources Center Contribution No. 697. Special acknowledgements are due to numerous researchers not included in this manuscript who have contributed to research efforts and manuscript preparation, including Rosario Sanay, M. Richard DeVoe, Fred Holland, Katherine Luciano, Samm Bruce, Dave Wells, Laura Coggins, and the SCDNR's and NOAA's Hollings Marine Laboratory staff who participated in the 2009 hypoxia response effort. We appreciate the valuable input from Kehui Xu and 3 anonymous reviewers.

\section{LITERATURE CITED}

Aretxabaleta A, Nelson JR, Blanton JO, Seim HE, Werner FE, Bane JM, Weisberg R (2006) Cold event in the South Atlantic Bight during summer of 2003: anomalous hydrographic and atmospheric conditions. J Geophys Res 111: C06007, doi:10.1029/2005JC003105

Anderson TH, Taylor GT (2001) Nutrient pulses, plankton blooms, and seasonal hypoxia in western Long Island Sound. Estuaries 24:228-243

Arar EJ, Collins GB (1997) Method 445.0: in vitro determination of chlorophyll $a$ and pheophytin $a$ in marine and freshwater algae by fluorescence. National Exposure Research Laboratory, Office of Research and Development, US Environmental Protection Agency, Cincinnati, $\mathrm{OH}$

Atkinson LP (1985) Hydrography and nutrients of the southeastern US continental shelf. In: Atkinson LP, Menzel DW, Bush KA (eds) Oceanography of the southeastern US continental shelf. Coast Estuar Sci 2:77-92

Atkinson LP, Blanton JO (1986) Processes that affect stratification in shelf waters. In: Mooers CNK (ed) Baroclinic processes in continental shelves. Coast Estuar Sci 3: $117-130$

Benner R, Strom M (1993) A critical evaluation of the analy- tical blank associated with DOC measurements by hightemperature catalytic oxidation. Mar Chem 41:153-160 Bianchi TS, DiMarco SF, Cowan JH Jr, Hetland RD, Chapman P, Day JW, Allison MA (2010) The science of hypoxia in the northern Gulf of Mexico: a review. Sci Total Environ 408:1471-1484

Blanton JO, Aretxabaleta AL, Werner FE, Seim H (2003) Monthly climatology of the continental shelf waters of the South Atlantic Bight. J Geophys Res 108(C8):3264, doi:10.1029/2002JC001609

Boesch DF, Rabalais NN (1991) Effects of hypoxia on continental shelf benthos: comparisons between the New York Bight and the northern Gulf of Mexico. In: Tyson RV, Pearson TH (eds) Modern and ancient continental shelf anoxia. Geological Society Special Publications No. 58, The Geological Society, London

Canuel EA, Zimmerman AR (1999) Composition of particulate organic matter in the lower Chesapeake Bay: sources and reactivity. Estuaries 22:980-994

> Carignan R, Blais AM, Vis C (1998) Measurement of primary production and community respiration in oligotrophic lakes using the Winkler method. Can J Fish Aquat Sci 55: 1078-1084

Chan F, Kirincich A, Barth J, Lubchenco J, Menge BA (2006) Upwelling-driven hypoxia off the central Oregon coast. In: Ocean Sci Meet Suppl. EOS Trans AGU 87:OS53J-06 (abstract)

Conley DJ, Humborg C, Rahm L, Savchuk OP, Wulff F (2002) Hypoxia in the Baltic Sea and basin-scale changes in phosphorus biogeochemistry. Environ Sci Technol 36: 5315-5320

Conley DJ, Carstensen J, Vaquer-Sunyer R, Duarte CM (2009) Ecosystem thresholds with hypoxia. Hydrobiologia 629:21-29

Connolly TP, Hickey BM, Geier SL, Cochlan WP (2010) Processes influencing seasonal hypoxia in the northern California Current System. J Geophys Res 115:C03021, doi:10.1029/2009JC005283

Diaz RJ, Rosenberg R (1995) Marine benthic hypoxia: a review of its ecological effects and the behavioral responses of benthic macrofauna. Oceanogr Mar Biol Annu Rev 33:245-303

> Diaz RJ, Rosenberg R (2008) Spreading dead zones and consequences for marine ecosystems. Science 321:926-929

Diaz RJ, Solow A (1999) Ecological and economic consequences of hypoxia: Topic 2 report for the integrated assessment on hypoxia in the Gulf of Mexico. NOAA Coastal Ocean Program Decision Analysis Series No. 16, NOAA Coastal Ocean Program, Silver Spring, MD

Glenn SM, Crowley MF, Haidvogel DB, Song YT (1996) Underwater observatory captures coastal upwelling events off New Jersey. EOS Trans AGU 77:233-236

Glenn S, Arnone R, Bergmann T, Bissett WP and others (2004) Biogeochemical impact of summertime coastal upwelling on the New Jersey Shelf. J Geophys Res 109:C12502, doi:10.1029/2003JC002265

Glibert PM, Mlodzinska Z, D'Elia CF (1977) A semiautomated persulfate oxidation technique for simultaneous total nitrogen and total phosphorus determination in natural water samples. Woods Hole Oceanographic Institution Contribution Number 3954, Ocean Industry Program of the Woods Hole Oceanographic Institution, Woods Hole, MA

Grantham BA, Chan F, Nielsen KJ, Fox DS and others (2004) Upwelling-driven nearshore hypoxia signals ecosystem and oceanographic changes in the northeast Pacific. Nature 429:749-754 
Gutierrez BT, Voulgaris G, Work PA (2006) Cross-shore variation of wind-driven flows on the inner shelf in Long Bay, South Carolina, USA. J Geophys Res 111:C03015, doi: 10.1029/2005JC003121

- Hagy JD, Boynton WR, Keefe CW, Wood KV (2004) Hypoxia in Chesapeake Bay, 1950-2001: long-term change in relation to nutrient loading and river flow. Estuaries 27: 634-658

> Haidvogel DB, Arango HG, Hedstrom K, Beckmann A, Malanotte-Rizzoli P, Shchepetkin AF (2000) Model evaluation experiments in the North Atlantic Basin: simulations in nonlinear terrain-following coordinates. Dyn Atmos Oceans 32:239-281

- Hamilton P (1987) Summer upwelling on the southeastern continental shelf of the USA during 1981: the structure of the shelf and Gulf Stream motions in the Georgia Bight. Prog Oceanogr 19:329-351

> Hawley N, Johengen TH, Rao R, Ruberg SA and others (2006) Lake Erie hypoxia prompts Canada-US study. EOS Trans AGU 87:313

Hoffmann EE, Pietrafesa LJ, Klinck JM, Atkinson LP (1980) A time-dependent model of nutrient distribution in continental shelf waters. Ecol Model 10:193-214

Hoffmann EE, Pietrafesa LJ, Atkinson LP (1981) A bottom water intrusion in Onslow Bay, North Carolina. DeepSea Res 28:329-345

Jiang LQ, Cai WJ, Wang Y, Diaz J, Yager PL, Hu X (2010) Pelagic community respiration on the continental shelf off Georgia, USA. Biogeochemistry 98:101-113

Kemp WM, Boynton WR, Adolf JE, Boesch DF and others (2005) Eutrophication of Chesapeake Bay: historical trends and ecological interactions. Mar Ecol Prog Ser 303:1-29

Koepfler ET (2010) Surface water and depth profile spatial patterns of hypoxia development along the Grand Strand, South Carolina. In: Proceedings of the 2010 South Carolina Water Resources Conference. Available at: http://media.clemson.edu/public/restoration/ scwrc/2010/manuscripts/t2/koepfler_10scwrcpaper.pdf (accessed 20/01/2011)

Lee TN, Pietrafesa LJ (1987) Summer upwelling on the southeastern continental shelf of the USA during 1981: circulation. Prog Oceanogr 19:267-312

Libes S, Kindelberger S (2010) Hypoxia in the nearshore coastal waters of South Carolina along the Grand Strand. In: Proceedings of the 2010 South Carolina Water Resources Conference. Available at: http://media.clemson. edu/public/restoration/scwrc/2010/manuscripts/t2/libes_ kindelberger_10scwrcpaper.pdf (accessed 20/01/2011)

MBCC (Myrtle Beach Chamber of Commerce) (2009) The Myrtle Beach statistical abstract, 19th edn. MBCC, Myrtle Beach, SC (accessed 12/01/2011)

McCarney-Castle K, Voulgaris G, Kettner AJ (2010) Analysis of fluvial suspended sediment load contribution through Anthropocene history to the South Atlantic Bight coastal zone, U.S.A. J Geol 118:399-416

McCoy CA, Viso RF, Peterson RN, Libes SM and others (2011) Radon as an indicator of limited cross-shelf mixing and submarine groundwater discharge in a coastal embayment along the South Atlantic Bight. Cont Shelf Res 31:1306-1317

> Murrell MC, Lehrter JC (2011) Sediment and lower water column oxygen consumption in the seasonally hypoxic region of the Louisiana Continental Shelf. Estuaries Coasts 34:912-924

Editorial responsibility: William Kemp,

Cambridge, Maryland, USA
Nixon SW, Buckley BA, Granger SL, Harris LA, Oczkowsk AJ, Fulweiler RW, Cole LW (2008) Nitrogen and phosphorus inputs to Narragansett Bay: past, present, and future. In: Desbonnet A, Costa-Pierce BA (eds) Science for ecosystem-based management. Springer, New York, NY

NOAA Coastal Change Analysis Program (2005) Digital coasts. Available at: www.csc.noaa.gov/digitalcoast/ data/ ccapregional/ (accessed 9 August 2010)

Pinckney JL, Paerl H, Tester P, Richardson T (2001) The role of nutrient loading and eutrophication in estuarine ecology. Environ Health Perspect 109:699-706

Rabalais NN, Diaz RJ, Levin LA, Turner RE, Gilbert D, Zhang J (2010) Dynamics and distribution of natural and human-caused hypoxia. Biogeosciences 7:585-619

Reynolds CS (2006) Ecology of phytoplankton. Cambridge University Press, Cambridge

Sanay R, Yankovsky A, Voulgaris G (2008) Inner shelf circulation patterns and nearshore flow reversal under downwelling and stratified conditions off a curved coastline. J Geophys Res 113:C08050, doi:10.1029/2007JC 004487

Sanger D, Hernandez D, Libes S, Voulgaris G and others (2010) A case history of the science and management collaboration in understanding hypoxia events in Long Bay, South Carolina, USA. Environ Manage 46:340-350

Shchepetkin AF, McWilliams JC (2005) The regional oceanic modeling system: a split-explicit, free-surface, topography-following coordinate oceanic model. Ocean Model 9:347-404

Smith EM, Kemp WM (2001) Size structure and the production/respiration balance in a coastal plankton community. Limnol Oceanogr 46:473-485

Sweet W, Zervas C, Gill S (2009) Elevated east coast sea levels anomaly: July-June 2009. NOAA Technical Report NOS CO-OPS 051, Silver Springs, MD

- Turner RE, Rabalais NN, Justic D (2006) Predicting summer hypoxia in the northern Gulf of Mexico: riverine N, P, and Si loading. Mar Pollut Bull 52:139-148

> Umlauf L, Burchard H (2003) A generic length-scale equation for geophysical turbulence models. J Mar Res 61: 235-265

US Travel Association (2009) The economic impact of travel on South Carolina counties, 2008. US Travel Association, Washington, DC

Verity PG, Alber M, Bricker SB (2006) Development of hypoxia in well-mixed subtropical estuaries in the southeastern USA. Estuaries Coasts 29:665-673

Voulgaris G, Sanay R (2010) Physical oceanographic constraints contributing to the development of low oxygen events in Long Bay, SC. In: Proceedings of the 2010 South Carolina Water Resources Conference. Available at: http://media.clemson.edu/public/restoration/scwrc/ 2010/manuscripts/t2/voulgarisg2_sanay_10scwrcpaper. pdf (accessed 20/01/2011)

Wiseman WJ Jr, Rabalais NN, Turner RE, Dinnel SP, MacNaughton A (1997) Seasonal and interannual variability within the Louisiana Coastal Current: stratification and hypoxia. J Mar Syst 12:237-248

Wu RSS (2002) Hypoxia: from molecular responses to ecological responses. Mar Pollut Bull 45:35-45

Zhang J, Gilbert D, Gooday AJ, Levin L and others (2010) Natural and human-induced hypoxia and consequences for coastal areas: synthesis and future development. Biogeosciences 7:1443-1467 